\title{
Management of severe acute exacerbations of COPD: an updated narrative review
}

\author{
Ernesto Crisafulli ${ }^{1}$, Enric Barbeta ${ }^{2}$, Antonella lelpo $^{1}$ and Antoni Torres ${ }^{2^{*}}$
}

\begin{abstract}
Background: Patients with chronic obstructive pulmonary disease (COPD) may experience an acute worsening of respiratory symptoms that results in additional therapy; this event is defined as a COPD exacerbation (AECOPD). Hospitalization for AECOPD is accompanied by a rapid decline in health status with a high risk of mortality or other negative outcomes such as need for endotracheal intubation or intensive care unit (ICU) admission. Treatments for AECOPD aim to minimize the negative impact of the current exacerbation and to prevent subsequent events, such as relapse or readmission to hospital.

Main body: In this narrative review, we update the scientific evidence about the in-hospital pharmacological and non-pharmacological treatments used in the management of a severe AECOPD. We review inhaled bronchodilators, steroids, and antibiotics for the pharmacological approach, and oxygen, high flow nasal cannulae (HFNC) oxygen therapy, non-invasive mechanical ventilation (NIMV) and pulmonary rehabilitation (PR) as non-pharmacological treatments. We also review some studies of non-conventional drugs that have been proposed for severe AECOPD.

Conclusion: Several treatments exist for severe AECOPD patients requiring hospitalization. Some treatments such as steroids and NIMV (in patients admitted with a hypercapnic acute respiratory failure and respiratory acidosis) are supported by strong evidence of their efficacy. HFNC oxygen therapy needs further prospective studies. Although antibiotics are preferred in ICU patients, there is a lack of evidence regarding the preferred drugs and optimal duration of treatment for non-ICU patients. Early rehabilitation, if associated with standard treatment of patients, is recommended due to its feasibility and safety. There are currently few promising new drugs or new applications of existing drugs.
\end{abstract}

Keywords: COPD, Acute exacerbation, Hospitalization, Steroids, Antibiotics, Oxygen, High flow nasal cannulae oxygen therapy, Non-invasive mechanical ventilation, Pulmonary rehabilitation

\section{Background}

In the natural history of disease, patients with chronic obstructive pulmonary disease (COPD) may experience an acute worsening of the clinical condition that is described as a COPD exacerbation (AECOPD) [1]. AECOPD may be triggered by respiratory viral and bacterial infection [2]; pollution or ambient temperature may also initiate or amplify AECOPD [2]. Characterized by increased systemic inflammatory activity [3], AECOPD has a negative impact on patients' health status and outcomes $[4,5]$.

\footnotetext{
* Correspondence: ATORRES@clinic.cat

${ }^{2}$ Pneumology Department, Clinic Institute of Thorax, Hospital Clinic of Barcelona - Institut d'Investigacions Biomèdiques August Pi i Sunyer (IDIBAPS), University of Barcelona, Barcelona, Spain

Full list of author information is available at the end of the article
}

\section{What is an AECOPD? Definitions}

The absence of homogeneity in the definition of an AECOPD has opened controversial opinions in the last few years. The possibility to define in the same ways the AECOPD could have implications on decision-making, changing therapeutic interventions in clinical trials $[6,7]$. In the ' 80 s, although the Anthonisen criteria [8] were based on patients' symptoms reporting an AECOPD (increase of dyspnea, sputum purulence and sputum volume), the presence of a change in sputum characteristics, with increased cough and wheeze, could identify an AECOPD needing a specific antibiotic approach. From Anthonisen criteria, several definitions have been proposed, but in general they are based on changes in patient symptoms (dyspnea, cough, sputum) or on healthcare resources requirement (drugs, hospitalisation), or on

(c) The Author(s). 2018 Open Access This article is distributed under the terms of the Creative Commons Attribution 4.0 International License (http://creativecommons.org/licenses/by/4.0/), which permits unrestricted use, distribution, and 
combinations of both $[6,7]$. In this context, the three recent documents related to experts consensus about management of AECOPD (the Global Initiative for Chronic Obstructive Lung Disease-GOLD document [1], the National Institute of Health and Clinical Excellence-NICE guidelines [9] and the European Respiratory Society/ American Thoracic Society ERS/ATS guidelines [10]) describe definitions of AECOPD based on onset of symptoms and need of additional therapy (Table 1). Although these definitions may be usefull in the clinical practice, this approach may be too pragmatic, oversimplifing the pathogenic pathways implicated [7]. Very recently, in a holistic approach, more precise definitions of AECOPD have been considered to include not only clinical variables [7, 11, 12]; this approach may be more accurate for the differential diagnosis with other respiratory diseases.

\section{When AECOPD is severe and needs a hospitalization}

Although the severity of AECOPD may be classified according to the use of medications [1], in severe AECOPD that requires hospitalization the early recognition of acute respiratory failure (ARF), either non-life- or life-threatening $[1,13]$ (Table 2), may be crucial for correct selection of treatment. Table 3 reports potential indicators for identifying when severe AECOPD patients require hospitalization in a medical ward or in a respiratory or medical intensive care unit (ICU) [1].

\section{Why a severe AECOPD is important?}

Hospitalization for AECOPD worsens the course of COPD disease and involves a rapid decline in health status associated with high mortality $[5,14,15]$. Although male gender has been identified as a risk factor for higher morbidity and mortality in AECOPD [14], recent data indicate that female COPD patients may have a higher number of hospitalizations with a prolonged length of stay [16]. In any case, severe AECOPD increases the possibility of subsequent COPD-related hospitalizations [5], with potential causal associations among past and future severe exacerbations [17]. This could be related also to a distinct phenotype of COPD, the frequent exacerbator [18], worsening the clinical outcomes [19]. In this context, a history of at least two prior incidents of severe AECOPD is associated with a new severe event (adjusted odds ratio
[OR] 6.73; 95\% confidence interval [CI], 3.53 to 12.83 ) and an increased risk of death (adjusted OR 7.63; 95\% CI 3.41 to 17.05) [20]. Variables related to age, low body mass index, cardiac failure, diabetes mellitus, ischemic heart disease, malignancy, forced expiratory volume in the $1^{\text {st }}$ second $\left(\mathrm{FEV}_{1}\right)$, long-term oxygen therapy, and the partial arterial oxygen pressure $\left(\mathrm{PaO}_{2}\right)$ on admission of severe AECOPD were significantly associated with long-term mortality during a 2-year follow up period [21]. The presence of coexisting asthma has also been proved to be associated with frequent severe AECOPD [22]. In general for a severe hospitalized AECOPD, the weighted average of the in-hospital mortality, and of the mortality at 1 year and 5 years, is $6.7 \%$ ( $95 \%$ CI 5.7 to 7.7 ), 33\% (95\% CI 25 to 40 ) and 51\% (95\% CI 38 to 63), respectively [23]. Recent evidence about worse outcomes in hospitalized AECOPD shows links with the presence of hyponatremia [24], hypoalbuminemia [25], ischemic heart disease [26], and acute kidney injury [27]. Recently, an English study reported that patients having a pulmonary arterial enlargement, defined by a pulmonary artery to aorta (PA/A) ratio $>1$ at chest CT scan, associated with an increased level of troponin $(>0.01 \mathrm{ng} / \mathrm{mL})$, had an increased probability of having ARF, ICU admission or in-hospital mortality in comparison to patients without both these factors [28].

\section{Why a treatment in a severe AECOPD is important?}

Treatments for AECOPD aim to minimize the negative impact of the current exacerbation and to prevent subsequent events [1], such as the relapse of AECOPD [29] and, in cases of hospitalization, reduce early readmissions to hospital [30] occurring within $\leq 30$ days of discharge. Although there are known predictors of early readmission [31-33], re-hospitalization for a new severe event is required in $18 \%$ of AECOPD patients admitted [34] and was associated with a subsequent progressive increase in the risk of death in a long-term follow up [34]; for this reason, early readmission should be considered in these patients as a marker of more severe disease with a worse prognosis [35]. Although the initial treatment may be a useful predictor of subsequent clinical outcomes [36], treatment failure, which occurs in $14 \%$ [37] to $18 \%$ [38] of treated patients, may be predicted by a measure of daily health status (by the Clinical COPD

Table 1 Definitions of AECOPD according to the GOLD document, NICE guidelines and ERS/ATS guidelines

\begin{tabular}{ll}
\hline GOLD document & Acute worsening of respiratory symptoms that results in additional therapy. \\
\hline NICE guidelines & A worsening of the patient's symptoms from their usual stable state which is beyond \\
& normal day-to-day variations, and is acute in onset. Commonly reported symptoms are \\
& worsening breathlessness, cough, increased sputum production and change in sputum \\
& colour. The change in these symptoms often necessitates a change in medication.
\end{tabular}


Table 2 Severity of hospitalized AECOPD patients

\begin{tabular}{|c|c|c|c|c|c|c|}
\hline Clinical scenario & $\begin{array}{l}\text { Respiratory rate } \\
\text { (breaths/minutes) }\end{array}$ & $\begin{array}{l}\text { Use of accessory } \\
\text { respiratory muscles }\end{array}$ & $\begin{array}{l}\text { Change in } \\
\text { mental status }\end{array}$ & $\begin{array}{l}\text { Supplemental oxygen given via } \\
\text { Venturi mask able to improve } \\
\text { hypoxemia }\left(\mathrm{FiO}_{2} \%\right)\end{array}$ & $\mathrm{PCO}_{2}$ & $\mathrm{pH}$ \\
\hline No respiratory failure & $20-30$ & No & No & $28-35$ & Normal & Normal \\
\hline $\begin{array}{l}\text { Acute respiratory failure } \\
\text { (non-life-threatening) }\end{array}$ & $>30$ & Yes & No & $35-40$ & $\begin{array}{l}\text { Increased } \\
(50-60 \mathrm{mmHg})\end{array}$ & Normal \\
\hline $\begin{array}{l}\text { Acute respiratory failure } \\
\text { (life-threatening) }\end{array}$ & $>30$ & Yes & Yes & $>40$ or not improved & $\begin{array}{l}\text { Increased } \\
(>60 \mathrm{mmHg})\end{array}$ & $\leq 7.25$ \\
\hline
\end{tabular}

Modified from references $[1,13]$

Abbreviations: $\mathrm{FiO}_{2}$ indicates fraction of inspired oxygen, $\mathrm{PaCO}_{2}$, partial arterial carbon dioxide pressure

Questionnaire-CCQ) [38]; moreover, an increased inflammatory level at admission (C-reactive protein [CRP] $+1 \mathrm{mg} / \mathrm{dL}$ OR $1.07 ; 95 \%$ CI 1.01 to 1.13 ) and the use of penicillins or cephalosporins (OR 5.63; 95\% CI 1.26 to 25.07) were independently associated with an increased risk of treatment failure, whereas cough at admission (OR $0.20 ; 95 \%$ CI 0.05 to 0.75 ) was associated with a lower risk [37].

In this narrative review, based on a search on Medline completed in the month of May 2018, we update the scientific evidence about the in-hospital pharmacological and non-pharmacological treatments used in the management of a severe AECOPD. For the pharmacological approach we have divided the evidence according to the class of drugs (inhaled bronchodilators, steroids, and antibiotics). Non-pharmacological treatments include the use of oxygen, high flow nasal cannulae (HFNC) oxygen therapy, and non-invasive mechanical ventilation (NIMV) and pulmonary rehabilitation (PR). Finally, we review some studies concerning non-conventional drugs that have also been proposed for severe AECOPD.

\section{Bronchodilators}

Although recommended with or without short-acting anticholinergics as the initial bronchodilators to treat an AECOPD, short-acting $\beta_{2}$ agonists (SABA) have no high-quality evidence from randomized-control trials [1]. The use of these medications is in line with recent treatment patterns of hospitalized patients [39] in which only $5 \%$ of patients did not receive a SABA, while $72 \%$ received a single-product SABA and $46 \%$ received a combination with SABA plus a short-acting anticholinergic [39].

Table 3 Potential indicators for do-not-hospitalize AECOPD patients or hospitalization in a general ward or in a respiratory or medical intensive care units (ICU)

\begin{tabular}{|c|c|c|c|}
\hline Variables & Do-not-hospitalize & General ward & Respiratory or medical ICU \\
\hline Insufficient home support & & $x$ & \\
\hline Good response to initial medical management & $x$ & & \\
\hline Failed response to initial medical management & & $x$ & \\
\hline $\begin{array}{l}\text { Fewer symptoms (dyspnea on effort, } \mathrm{RR}<30 \\
\text { breaths } / \text { min, } \mathrm{SatO}_{2}>90 \% \text {, no confusion, no drowsiness) }\end{array}$ & $x$ & & \\
\hline $\begin{array}{l}\text { Severe symptoms (resting dyspnea, RR } \geq 30 \text { breaths/min, } \\
\mathrm{SatO}_{2} \leq 90 \% \text {, confusion, drowsiness) }\end{array}$ & & $x$ & \\
\hline $\begin{array}{l}\text { Very severe symptoms (dyspnea) that respond inadequately } \\
\text { to initial emergency therapy }\end{array}$ & & & $x$ \\
\hline $\begin{array}{l}\text { Presence of serious comorbidities (e.g. heart failure, newly } \\
\text { occurring arrhythmias, etc.) }\end{array}$ & & $x$ & \\
\hline Onset of new physical signs (e.g. cyanosis, peripheral edema) & & $x$ & \\
\hline $\begin{array}{l}\text { Acute respiratory failure (without use of accessory respiratory } \\
\text { muscles and change in mental status) }\end{array}$ & & $x$ & \\
\hline $\begin{array}{l}\text { Acute respiratory failure (with use of accessory respiratory } \\
\text { muscles and change in mental status) }\end{array}$ & & & $x$ \\
\hline $\begin{array}{l}\text { Persistent or worsening hypoxemia }\left(\mathrm{PO}_{2}<40 \mathrm{mmHg}\right) \\
\text { and/or severe respiratory acidosis }(\mathrm{pH}<7.25)\end{array}$ & & & $x$ \\
\hline Need for IMV & & & $x$ \\
\hline Hemodynamic instability (need for vasopressors) & & & $x$ \\
\hline
\end{tabular}

Modified from report [1]. The cross mark identifies the correct setting

Abbreviations: $R R$ indicates respiratory rate, $\mathrm{SatO}_{2}$ oxygen saturation, $\mathrm{PaO}_{2}$ partial arterial oxygen pressure, $I M V$ invasive mechanical ventilation 
A Canadian meta-analysis performed in COPD patients with an acute airflow obstruction found no difference in the effect of bronchodilator delivery by a metered-dose inhaler (MDI) or wet nebulizer based on objective measurements [40]. Similarly, a recent Cochrane review comparing the effects of nebulizers versus pressurized MDI (pMDI) plus spacer or dry powder inhalers (DPI) [41] found no significant difference in the change in $\mathrm{FEV}_{1}$ at $1 \mathrm{~h}$ after dosing between nebulizers versus pMDI plus spacer although there was a trend for greater improvement in $\mathrm{FEV}_{1}$ when treating with nebulizers [41]. No data of sufficient quality have been published comparing nebulizers versus DPIs [41]. In conclusion, the limitations of the difficult-to-pool and low-quality data did not permit the authors to provide evidence to favor one mode of delivery over another [41].

In general, spacer devices are recommended for bronchodilator delivery with a pMDI [1]. A study evaluating the necessary inspiratory flow using different DPIs in patients admitted to hospital during an AECOPD demonstrated the ability of patients to use these inhalers [42]. At admission, the median (interquartile range) of inspiratory flow (L/minutes) using the appropriate simulators of the resistance and the percentage of patients (\%) achieving the minimum necessary inspiratory flow of $30 \mathrm{~L} / \mathrm{min}$ required for each DPI device were $40 \mathrm{~L} / \mathrm{m}$ (30-50) (91\%), $50 \mathrm{~L} / \mathrm{m}$ (40-60) (95\%), $60 \mathrm{~L} / \mathrm{m}$ (50-87.5) (100\%), and $30 \mathrm{~L} / \mathrm{m}(20-40)(82 \%)$ for Turbuhaler ${ }^{\circ}$, Diskus ${ }^{\circ}$, Aerolizer $^{\circ}$, and Handihaler ${ }^{\circ}$, respectively [42]. This might open up the possibility of using long-acting $\beta_{2}$ agonists (LABA) for the treatment of AECOPD [43]. A proof of concept [44] performed in AECOPD patients having a mild-to-moderate worsening of dyspnea demonstrated that an early treatment with doubling dose of a combination of a LABA (Salmeterol) plus an inhaled corticosteroid (ICS, Fluticasone Propionate) for 10 days has a potential effect avoiding the requirement of prednisone within 30 days of the onset. In a single-center, open-label, randomized, crossover, and single-blind trial on 12 hospitalized AECOPD patients, a recent study exploring the acute effect of indacaterol found a significant mean increase in $\mathrm{FEV}_{1}$ and forced vital capacity (FVC), with the highest increase at the dose of $300 \mathrm{mg}$; however, transient episodes of oxygen desaturation were observed in some patients with relatively well-preserved $\mathrm{PaO}_{2}$ $(-5.9 \mathrm{mmHg}$ [95\% CI -1.4 to -10.4$]$ and $-6.2 \mathrm{mmHg}$ [95\% CI -2.7 to -9.8 ] in the mean peak in $\mathrm{PaO}_{2}$ over $6 \mathrm{~h}$ in the group treated with indacaterol $150 \mathrm{mg}$ and indacaterol $300 \mathrm{mg}$, respectively) [45]. Similar increases were observed when indacaterol was administered over 5 days in the emergency department in comparison to salbutamol [46].

\section{Main take home messages}

The large use of SABA and short-acting anticholinergics during an AECOPD is a common therapeutic practice, although to date there are not solid evidences. There are also limitated data about the better bronchodilator delivery. The use of LABA during AECOPD, although limitated, could have large employ in the manteinance therapy after discharge.

\section{Unmet needs or future clinical research}

There are not quality data about the use of long-acting muscarinic antagonists (LAMA) during a severe AECOPD. In the era of dual bronchodilation in the treatment for COPD [47] this represents a strong unmet needs that should be investigated.

\section{Steroids}

There is strong evidence for the use of systemic steroids in severe AECOPD [10]. This has been reported in the recent European Respiratory Society/American Thoracic Society consensus guideline providing clinical recommendations for the treatment of AECOPD [10].

Several studies have demonstrated an improvement of several outcomes in AECOPD patients using systemic steroids, including length of hospital stay [48, 49], in-hospital oxygenation [48, 49], $\mathrm{FEV}_{1}$ [48-50], dyspnea [50], risk of relapse [50], and rate of treatment failure $[49,51]$. Prednisone/prednisolone is the preferred intravenous or oral steroid $[48,50,52-54]$. The oral administration of prednisolone is as effective as intravenous administration [53]. A short duration of treatment is preferred to a long duration [52, 55]. Several studies have been performed on hospitalized AECOPD but not on ICU patients [48-50], while some have been performed in critically ill patients $[51,56]$.

In 1999, two studies $[48,49]$ performed in patients without ARF and placebo-control demonstrated the efficacy of oral prednisolone (30 $\mathrm{mg}$ for 14 days) [48] and intravenous methylprednisolone $(500 \mathrm{mg}$ for 3 days followed by oral prednisone $60 \mathrm{mg}$ for 4 days with a scalar dose until 8 or 2 weeks, according to the study group) [49] at improving $\mathrm{FEV}_{1}$ and reducing hospital stay. For the first time in trials, the latter study [49] reported treatment failure as a primary outcome, defined by the assessment of in-hospital deaths due to any cause, the need for NIMV or ICU admission, hospital readmission, and the need for intensification of therapy. The authors demonstrated a lower rate of combined failure variables at 30 days $(23 \%$ versus $33 \%, p=0.04)$ and at 90 days (37\% versus $48 \%, p=0.04$ ) in patients using steroids in comparison to placebo [49]. Finally, in a three-arm design (patients receiving 8 or 2 weeks of steroids and patients receiving placebo) it was demonstrated that the long steroid regimen of 8 weeks did not 
increase the clinical benefits of a short regimen of 2 weeks [49].

To study the outcomes of the risk of relapse after a severe AECOPD, Aaron and colleagues [50] enrolled AECOPD patients who were being discharged from the emergency department and treated with $40 \mathrm{mg}$ of oral prednisone for 10 days. The authors found a lower rate of relapse at 30 days $(27 \%$ versus $43 \%, p=0.05)$ and a longer time to relapse (23 days versus 7 days, hazards ratio 0.56 [95\% CI 0.32 to 0.99 ], $p=0.04$ ) in patients with steroids versus placebo [50]. Furthermore, patients treated with prednisone showed improvements in their $\mathrm{FEV}_{1}$ (from day 1 to day 10) and dyspnea scores [50].

Studies performed specifically in mechanically ventilated AECOPD patients or those admitted to the ICU include the Spanish double-blind, placebo-controlled trial of Alía and colleagues [51], which was performed on 83 acidotic AECOPD patients who received intravenous methylprednisolone (from a dose of $2 \mathrm{mg} / \mathrm{kg} /$ day for 3 days to $0.5 \mathrm{mg} / \mathrm{kg} /$ day from days 7 through 10). Patients in the steroid group showed a reduction in the duration of mechanical ventilation in comparison to placebo (median [interquartile range], 3 days [2-6] versus 4 days [3-7], $p=0.04$, respectively) [51]; however, when comparing patients with conventional ventilation (46 patients) and NIMV (37 patients) the use of steroids did not appear to reduce the duration of ventilation in comparison to the placebo. Interestingly, the rate of NIMV was lower in the steroid group (0\%) in comparison to the placebo (37\%). Another prospective, open-label, randomized, placebo-controlled trial on the use of oral prednisone $(1 \mathrm{mg} / \mathrm{kg} /$ day for up to 10 days) performed on 217 acidotic AECOPD patients requiring initial conventional mechanical ventilation $(n=53)$ or NIMV $(n=$ 164), found contrasting findings [56]. There was no difference in primary outcomes (ICU mortality, evaluated in all ventilated and in conventional and NIMV) or secondary outcomes (failure of NIMV, duration of mechanical ventilation, ICU length of stay) [56]. The different doses of steroid used in the studies [51, 56] and the severity of AECOPD (more severe respiratory acidosis and hypercapnia in the latter [56]) may explain the different results.

With regards to the route of steroid administration (parenteral versus oral), a study has demonstrated that oral administration with prednisolone ( $60 \mathrm{mg}$ for 5 days) was no less effective than intravenous therapy [53], with no difference in treatment failure in the early phase (within 2 weeks) or at 90 days. The length of hospital stay, moreover, was similar among the oral administration (11.2 days) and the intravenous therapy group (11.9 days) [53]. A recent study [57] comparing AECOPD patients receiving a fixed, low dose of oral steroids (methylprednisolone $32 \mathrm{mg}$ /day for 7 days) with patients receiving higher doses of intravenous steroids (methylprednisolone at $1 \mathrm{mg} / \mathrm{kg} /$ day for 4 days and $0.5 \mathrm{mg} / \mathrm{kg} /$ day for 3 days) demonstrated similar results between study groups in terms of lung function, symptoms and oxygenation [57]. In line with these findings about the optimal dose and route of steroid administration, a pharmacoepidemiological cohort study conducted in more than 400 US hospitals involving almost 80,000 AECOPD patients [58] demonstrated that the risk of treatment failure (initiation of mechanical ventilation, in-hospital mortality, or readmission for AECOPD within 30 days of discharge) among patients treated with low doses of steroids administered orally was not worse than for those treated with higher doses administered intravenously [58]. In the context of the optimal dose of steroids in AECOPD patients treated in the ICU, another recent pharmacoepidemiological cohort study [59] performed in 473 hospitals on more than 17,000 patients examined the effectiveness and safety of a lower dose (methylprednisolone $\leq 240 \mathrm{mg} /$ day) versus a higher dose (methylprednisolone $>240 \mathrm{mg} /$ day) of steroids [59]. The authors found that patients using lower versus higher doses of steroids had similar hospital mortality (OR $0.85 ; 95 \%$ CI 0.71 to $1.01 ; p=0.06$ ), defined as a primary outcome. However, a lower dose of steroids was associated with a reduced length of hospital and ICU stay, hospital costs, length of invasive ventilation, need for insulin therapy, and fungal infection [59].

Based on the concept that the use of systemic corticosteroids for a longer time is associated with adverse effects such as osteoporosis, hyperglycemia and muscle weakness, the noteworthy trial of Leuppi and colleagues [52] (REDUCE: Reduction in the Use of Corticosteroids in Exacerbated COPD), published in 2013, defined the optimal dose (prednisone $40 \mathrm{mg}$ daily) and duration of steroid treatment (5 days) in hospitalized AECOPD. The short-term treatment of 5 days, in fact, was non-inferior to conventional treatment (14 days). The percentage of patients having a new exacerbation (median 180 days of follow up) was lower in the short-term treatment in comparison to conventional treatment (36\% versus $37 \%, p=0.006$ for the intention-to-treat [ITT] analysis, and $37 \%$ versus $38 \%, p=0.005$ in the per-protocol [PP] analysis, respectively). Similarly, the duration of hospital stay was lower (median 8 days [IQR 5-11] versus 9 days [IQR 6-14]; $p=0.04$, respectively) and the cumulative prednisone dose (difference in mean-414 mg.; $p<0.001$ ) was lower in the short-term group in comparison to the conventional group [52]. A Cochrane review, updated in 2018 [55] suggests that in a severe AECOPD the likelihood of having a worse outcome is lower in patients using an oral steroid for 5 days than with a longer course (10 to 14 days) [55]. This review [55], however, excluded studies with patients requiring assisted ventilation. In this 
context, a previous study performed on AECOPD requiring hospitalization but with ARF and comparing the same dose of methylprednisolone $(2 \mathrm{mg} / \mathrm{kg} /$ day $)$ but with different duration (3 or 10 days) [60] did not confirm that a short treatment is better for these patients. In fact, although both study groups (3 and 10 days) experienced improvements in oxygenation and $\mathrm{FEV}_{1}$, and the re-exacerbation rate at 6 months was similar, the improvements were more marked over the course of 10 days of steroids, as were those in FVC and dyspnea on exertion [60].

Although domiciliary inhaled corticosteroids do not influence the early inflammatory response and the clinical presentation of hospitalized AECOPD [61], the use of these medications during an AECOPD may be a valid alternative to systemic steroids for hospitalized patients as well; this approach might reduce the risk of side effects. A multicenter, double-blind, randomized, placebo-controlled trial performed on 199 not acidotic and not hypercapnic AECOPD patients compared nebulized budesonide ( $2 \mathrm{mg}$ four times/day) and oral steroids (prednisolone $60 \mathrm{mg} /$ day) [62]. In comparison to placebo, both treatments (budesonide and prednisolone) demonstrated an improvement in post-bronchodilator $\mathrm{FEV}_{1}$ and the difference between the two groups was not significant [62]. Another trial [63] performed on AECOPD patients without a severe airflow obstruction and without a ARF (hypercapnic patients with a partial arterial carbon dioxide pressure- $\mathrm{PaCO}_{2}>70 \mathrm{mmHg}$ were excluded a priori), was aimed to evaluate the clinical efficacy of comparison between nebulized budesonide ( $2 \mathrm{mg}$ three times/ day) versus intravenous methylprednisolone $(40 \mathrm{mg} /$ day). Both groups showed similar improvements in symptoms, pulmonary function and arterial blood gas analysis, although the incidence of adverse events was lower in the budesonide group [63].

\section{Main take home messages}

The use of steroids during a severe AECOPD appears justified from solid evidences. This is confirmed by improvements on several in-hospital (symptoms, length of hospital stay, treatment failure) and post-discharge (risk of relapse) outcomes. The oral administration should be preferred due to the similar efficacy of intravenous and for the limitation of systemic effects.

\section{Unmet needs or future clinical research}

In COPD patients molecular and immunological mechanisms of steroid resistance are documented [64]. To identify a cluster of steroid-responder patients could highlight a different therapeutic approach in the management of severe AECOPD.

\section{Antibiotics}

Data coming from sputum cultures suggest that bacterial infection is a more prevalent cause of AECOPD $[2,65,66]$, with a correlation between sputum color and the presence of potentially pathogenic bacteria [67, 68]. In general, a sputum color of green or yellow was most likely to yield potentially pathogenic microorganisms $(59 \%$ and $45 \%$, respectively), in comparison to clear (18\%) and rust-coloured sputum (39\%) [67]; sputum color predicts a positive culture [67]. In severe AECOPD patients requiring mechanical ventilation, potentially pathogenic microorganisms (PPMs) and/or a positive serology were present in $72 \%$ of patients [69]. A bronchial microbiological pattern corresponding to community-acquired pathogens (Streptococcus pneumoniae, Haemophilus influenzae, and Moraxella catarrhalis) was present in $56 \%$ of positive samples, while a high percentage of positive samples (44\%) contained gram-negative enteric bacilli (GNEB), Pseudomonas, and Stenotrophomonas spp. [69]. Interestingly, the presence of pathogens was clinically unpredictable [69]. Being a non-current smoker, $\geq 2$ AECOPD or $\geq 1$ admission for AECOPD in the previous year and a CRP $<5 \mathrm{mg} / \mathrm{dL}$ were proved to be independent factors predicting the presence of microorganisms resistant to conventional treatment (MRCT) (40\% of isolates in hospitalized AECOPD patients) [70]; in this context, although patients with MRCT had longer hospital stays, the mortality rate at 30 days, 1 year and 3 years was comparable to that of patients with microorganisms sensitive to conventional antimicrobial treatment (MSCT) [70]. In any case, the use of antibiotics is recommended in AECOPD with sputum purulence and especially for very severe patients [67-70].

Recently, with the aim of differentiating among chronic colonization and acute infection in AECOPD patients, levels of procalcitonin have been considered as a marker for the use of antibiotics [71, 72]. An updated Cochrane meta-analysis [73] showed that in acute respiratory tract infections the use of procalcitonin is useful to initiate or discontinue antibiotics; this results in lower risks of mortality, lower antibiotic consumption, and lower risk for antibiotic-related side effects [73]. In severe AECOPD patients with low serum procalcitonin values $(<0.1 \mathrm{ng} / \mathrm{ml})$, treatment with antibiotics has no benefits in comparison to placebo [74].

The use of antibiotics in AECOPD without signs of infections remains controversial [1]. The recommendation regarding length of antibiotic therapy (5 to 7 days) in AECOPD $[1,75]$ originates from the use of levofloxacin $500 \mathrm{mg}$, which has achieved clinical and bacteriological success regardless of the therapeutic course (5 or 7 days) [75]. However, this evidence was obtained in patients being managed in the community as either general practice patients or outpatients [75] and not in hospitalized severe AECOPD patients. A Cochrane review [76] showed 
that in AECOPD patients who need hospital admission for severe exacerbations, antibiotics reduce treatment failures (risk ratio $0.77,95 \%$ CI 0.65 to 0.91 , quality of evidence GRADE [Grading of Recommendations, Assessment, Development and Evaluation]: high) but not the length of hospital stay or mortality (low grade of evidence) [76]. The role of antibiotics is clearer in patients admitted to the ICU [76], even if documented in only one study [77]. Antibiotics reduce treatment failures up to 4 weeks (risk ratio $0.19,95 \%$ CI 0.08 to 0.45 , quality of evidence GRADE: high), all-cause mortality (odds ratio $0.21,95 \%$ CI 0.06 to 0.72 , quality of evidence GRADE: high), and length of hospital stay (mean difference -9.60 days; $95 \%$ CI -12.84 to -6.36 days) [76]. The authors concluded that the benefits of antibiotics in the ICU are evident [76], while in inpatients the evidence is inconsistent and stems from old studies [78-80].

With regards to the choice of antibiotic, a randomized, placebo-controlled trial in 2010 evaluated the effects of doxycycline $(200 \mathrm{mg})$ in addition to systemic corticosteroids [81]. On day 30 treatment success (the primary outcome defined as the cure or improvement of signs and/or symptoms of AECOPD, without sign or symptoms of infection) was not significant in intentionto-treat analysis (OR $1.3 ; 95 \%$ CI 0.8 to $2.0 ; p=0.32$ ) or per-protocol [81]. The clinical success at 10 days (secondary outcome) favored doxycycline (OR 1.9; 95\% CI 1.1 to $3.2 ; p=0.03$ ) only in ITT, but not in PP. Furthermore, at 10 days doxycycline was superior to placebo in term of change in bacteriological response, serum CRP and symptom scores, in particular cough and sputum purulence [81].

A cornerstone study about the use of antibiotics in severe AECOPD but requiring mechanical ventilation was the prospective, randomized, double-blind, placebo-controlled trial of Nouira and colleagues [77], who evaluated the effects of a fluoroquinolone, ofloxacin (400 mg for 10 days). In comparison to the placebo $(n=46)$, patients using ofloxacin $(n=47)$ had a reduction in primary outcomes, in particular percentage of deaths in the ICU ( $4 \%$ versus $17 \%, p=0.05$ ), deaths in hospital ( $4 \%$ versus $22 \%, p=0.01$ ), need for additional course of antibiotics $(6 \%$ versus $35 \%, p=0.0006)$, and combined events $(11 \%$ versus $57 \%, p<0.0001)$ [77]. Similarly, in terms of secondary outcomes ofloxacin was superior to placebo in number of days of mechanical ventilation (mean 6.4 days \pm 3.1 versus 10.6 days $\pm 5.1, p=0.04$ ), duration of ICU stay (mean 9.4 days \pm 5.2 versus 14.5 days $\pm 6.0, p=0.02$ ), and duration of hospital stay (mean 14.9 days \pm 7.4 versus 24.5 days $\pm 8.5, p=0.01$ ) [77]. The same researchers in the same series of patients $(n=170)$ evaluated the combination of trimethoprim and sulfamethoxazole $(160 / 800 \mathrm{mg}$ twice daily for 10 days) versus ciprofloxacin (750 mg twice daily for
10 days) in a randomized, double-blind trial [82]. In this case, the number of deaths in hospital or the ICU, the need for additional antibiotics, and the combined events (considered primary outcomes) were similar between study groups, including the duration in days of mechanical ventilation, the duration of hospital or ICU stay, and the exacerbation-free interval (secondary outcomes) [82]. The authors concluded that the efficacy of trimethoprim-sulfamethoxazole was similar to that of ciprofloxacin [82].

\section{Main take home messages}

In AECOPD with history of purulent sputum an antibiotic is suggested, although the role of this treatment in hospitalized AECOPD appears controversial and not fully clear. In patients admitted in ICU it seems have the major benefit. The levels of procalcitonin could better identify patients needing an antibiotic therapy.

\section{Unmet needs or future clinical research}

Although GOLD guidelines recommend an antibiotic therapy for 5 to 7 days [1], there is not a strong evidence about the choice of antibiotic and the duration of treatment.

\section{Oxygen therapy, high flow nasal cannulae (HFNC) oxygen therapy, and non-invasive mechanical ventilation (NIMV)}

The routine use of titrated oxygen treatment is recommended in hospitalized AECOPD, due to the lower risk of death and lower likelihood of respiratory acidosis or hypercapnia than in patients who received high flow oxygen [83]. Blood gases should be monitored to ensure a good level of oxygenation without carbon dioxide retention and/or worsening acidosis; the $\mathrm{PaO}_{2}$ should be maintained at $7.3-10 \mathrm{kPa}\left(\mathrm{SaO}_{2} 85-92 \%\right)$ to avoid the dangers of hypoxia and acidosis [84]. A recently developed device $\left(\mathrm{FreeO}_{2}\right)$ automatically adjusts the oxygen flow rates based on patients' needs, in order to limit hyperoxia and hypoxemia in hospitalized AECOPD patients [85]. In comparison to manual oxygen titration this device improved the percentage of time within the target $\mathrm{SaO}_{2}$ (significantly higher with $\mathrm{FreeO}_{2}$ ) and the time with severe desaturation and hyperoxia (reduced with $\mathrm{FreeO}_{2}$ ); furthermore, the length of hospital stay was lower in patients using $\mathrm{FreeO}_{2}$ [85].

HFNC oxygen therapy is a recent and easy therapeutic methodical, able to deliver high fraction of inspired oxygen $\left(\mathrm{FiO}_{2}\right)$, generating a low level of positive pressure and providing a washout of nasopharyngeal dead space [86-89]. The effects of HFNC increase the end-expiratory lung volume, improve the oxygenation and the breathing pattern, reduce the work of breathing [86-89]. It is considered an alternative for patients with severe hypoxemic ARF [86], although in comparison to conventional oxygen 
therapy and NIMV, a recent systematic review with a meta-analysis did not show for the HFNC a significant reduction of intubation rate and mortality [90]. Similary, a Cochrane review [91], due to very limited data, is unable to demonstrate whether HFNC provides an efficacy respiratory support for adult ICU patients. In addition, some risks of bias among included studies, differences in patient groups, and high levels of statistical heterogeneity for some outcomes, lead to uncertainty results [91].

The role of HFNC in stable hypercapnic patients has been recently demonstrated as safe [92, 93]. HFNC leads to a flow-dependent reduction in hypercapnia level; this is most likely achieved by a washout of the respiratory tract and a functional reduction in dead space [93].

In 24 AECOPD hospitalized patients, a single-centre randomized-controlled cross-over trial has evaluated the short-term effects of HFNC on $\mathrm{PaCO}_{2}$ level [94]. Both interventions (HFNC at $35 \mathrm{l} / \mathrm{min}$ and standard oxygen delivered via nasal prongs) were administred for $30 \mathrm{~min}$, with oxygen titrated to maintain the patient's baseline saturation and with $15 \mathrm{~min}$ of washout between interventions. The difference in transcutaneous carbon dioxide tension $\left(\mathrm{PtCO}_{2}\right)$ at $30 \mathrm{~min}$ (primary outcome) was lower for HFNC compared with standard oxygen ($1.4 \mathrm{mmHg} ; 95 \% \mathrm{CI}-2.2$ to $-0.6 ; p=0.001$ ). At $30 \mathrm{~min}$, however, there was no difference between groups in $\mathrm{SaO}_{2}$ and respiratory rate [94].

In 88 severe AECOPD with moderate hypercapnic ARF the clinical effectiveness of HFNC has been evaluated in a very recent prospective observational trial in comparison to NIMV [95] and has failed to demonstrate any significative effect. The intubation rate and the 30-day mortality were similar between groups, such as $\mathrm{pH}, \mathrm{PaO}_{2}$ and $\mathrm{PaCO}_{2}$ after 6 and $24 \mathrm{~h}$ [95]. However, this study reports methodological, inherent bias and tecnical (setting of NIMV) limits that probably can be explained for different levels of treatment [96].

In COPD patients, the increase in $\mathrm{PaCO}_{2}$ level with respiratory acidosis is associated with a worse outcome $[84,97,98]$, including the risk of ICU admission [84] or death $[84,97,98]$. Several randomized trials have demonstrated the efficacy of NIMV (using bilevel positive airway pressure) in AECOPD in comparison to standard care [99-103]; for this reason data from the Healthcare Cost and Utilization Project's Nationwide Inpatient Sample confirm that the use of this treatment has increased significantly over time among patients hospitalized for AECOPD, whereas the need for intubation and in-hospital mortality has declined [104]. The official ERS/ATS clinical practice guidelines about noninvasive ventilation for acute respiratory failure [105], providing evidence-based recommendations, report that in AECOPD patients the use of NIMV in patients with ARF leading to acute or acuteon-chronic respiratory acidosis $(\mathrm{pH} \leqslant 7.35)$ is strongly recommended (GRADE: high level of evidence), while a conditional recommendation with low certainty of evidence is reported for the prevention of acute respiratory acidosis $\left(\mathrm{PaCO}_{2}\right.$ normal or elevated but $\mathrm{pH}$ normal) [105]. In the context of respiratory acidosis, NIMV is important to avoid endotracheal intubation and invasive mechanical ventilation in patients with mild to moderate acidosis and respiratory distress, with the aim of preventing deterioration to a point when invasive ventilation would be considered [105]. The authors of the ERS/ATS guidelines [105] suggest considering NIMV in AECOPD patients who develop acute respiratory acidosis during hospital admission, in particular when the $\mathrm{pH}$ is $\leqslant 7.35, \mathrm{PaCO}_{2}$ is > $45 \mathrm{mmHg}$ and the respiratory rate is $>20-24$ breaths $/ \mathrm{mi}-$ nute despite standard medical therapy [105]. The authors suggest that there is no lower limit of $\mathrm{pH}$ below which a trial of NIV is inappropriate even if close monitoring is needed in patients with a lower $\mathrm{pH}$ due to a greater risk of failure due to the possibility of a rapid endotracheal intubation [105]. Previous [106] and recent Cochrane reviews [107] confirm the effectiveness of NIMV on very severe outcome such as need for endotracheal intubation and mortality, and the magnitude of advantages appears similar for patients with mild acidosis ( $\mathrm{pH} 7.30$ to 7.35 ) versus severe $(\mathrm{pH}<7.30)$, and when NIMV is applied in the ICU or in a ward setting [107].

A cornerstone study about NIMV in hospitalized AECOPD was conducted by Brochard and colleagues [99]. In a prospective, randomized study comparing NIMV plus standard treatment (oxygen until a maximal flow rate of $5 \mathrm{~L} / \mathrm{m}$ by nasal prongs, in order to achieve an arterial oxygen saturation above $90 \%$, antibiotics, bronchodilators, and corticosteroids or/and aminophylline) versus standard treatment in patients admitted to the ICU, the authors demonstrated a reduction in the need for endotracheal intubation (26\% versus $74 \%, p<0.001$ in NIMV and standard therapy, respectively). Furthermore, the percentage of complications not present on admission (such as pneumonia, barotrauma, gastrointestinal hemorrhage, renal insufficiency, neurologic events, and pulmonary embolism) (16\% versus $48 \%, p=0.001)$, the mean length of hospital stay ( $23 \pm 17$ days versus $35 \pm 33$, $p=0.005)$, and the mortality rate $(9.3 \%$ versus $28.5 \%$, $p=0.02$ ) were lower in the NIMV group in comparison to standard treatment [99]. The same outcomes have been demonstrated in other trials, including in patients admitted to a general respiratory ward [102, 108], or performed on patients with different etiologies of ARF other than COPD (non-COPD-related pulmonary process, neuromuscular disease, and status post-extubation) [103]. Improvements in dyspnea sensation after NIMV use have also been documented [109, 110]. Finally, the long-term survival of AECOPD patients was better in those treated with NIMV [111]. 
To evaluate the cost effectiveness of NIMV an incremental cost analysis per in-hospital death of 236 patients with mild to moderate respiratory acidosis $(\mathrm{pH} 7.25-$ 7.35) due to a severe AECOPD and admitted to 14 medical wards in the United Kingdom was performed [112]. Patients receiving NIMV had a reduction in costs of $£ 49.362$ (78.741 \$; $73.109 €$ ), mainly through reduced use of ICU admission [112]. The incremental cost effectiveness ratio was $-£ 645 /$ death avoided (95\% CI $-£ 2310$ to $£ 386)$, demonstrating that NIMV is a highly cost-effective strategy [112].

Generally, NIMV requires the use of facial or nasal interfacies that are key variables for the success of treatment $[113,114]$. However, a recent study demonstrated, during an episode of acute hypercapnic respiratory failure, that a new helmet may be a valid alternative to a mask in improving gas analysis, achieving a good tolerance [115]. Therefore, the sequential use of a mask and helmet diminished the incidence of failure [116]. Finally, an open mouthpiece method of ventilation, similar to traditional NIV delivered by a nasal mask, has been reported to be a useful technique, preventing further deterioration of gas exchange in AECOPD patients with mild to moderate acidosis [117]. According to strategies to improve the optimization of patient-ventilator interactions, the analysis of flow and pressure waveforms generated by ventilators can be useful [118]; optimized ventilation led to a more rapid normalization of $\mathrm{pH}$ at $2 \mathrm{~h}$, to a significant improvement of the patient's tolerance to ventilation at $2 \mathrm{~h}$, and to a higher reduction in $\mathrm{PaCO}_{2}$ at 2 and $6 \mathrm{~h}$ [118].

Among strategies to improve the efficacy of NIMV the use of an inhaled helium/oxygen mixture (heliox) instead of an air/oxygen mixture has been proposed as adjunctive therapy to NIMV in severe AECOPD. The rationale for the use of helium is related to the low density of this element in comparison to air. Physiologically, in 10 patients with AECOPD heliox reduced the work of breathing and $\mathrm{PCO}_{2}$ levels without significantly changing their breathing pattern or oxygenation [119]. Although a helium/oxygen mixture improves respiratory acidosis and the respiratory rate more quickly than air/ $\mathrm{O}_{2}$ [120], some recent trials in hypercapnic AECOPD patients found no significant effects of helium/oxygen mixture on clinical outcomes, such as the rate of NIMV failure [120-122] or intubation rate [123].

Regarding predictors of NIMV failure, the severity of hypercapnia and acidosis at admission are associated with the early failure of treatment $[111,124]$, while improvements in acidosis and respiratory rate after $4 \mathrm{~h}$ of NIMV were associated with success. Charts of risk describe the probability of failure in ARF patients treated with NIMV [125]. Very recently, the early and noninvasive ultrasound evaluation of diaphragmatic dysfunction
(DD) during severe AECOPD has been proved to be reliable and accurate in identifying patients at major risk for NIMV failure and worse prognosis [126]. Patients with $\mathrm{DD}$, evaluated by a change in diaphragm thickness $(\Delta$ Tdi $)<20 \%$ during tidal volume, had a higher risk for NIMV failure than patients without DD (risk ratio 4.4; $p$ $<0.001$ ), and this was significantly associated with higher in-hospital and 90-day mortality rates, longer mechanical ventilation duration, higher tracheostomy rate, and longer ICU stay [126]. The accuracy to predict failure by $\Delta \mathrm{Tdi}<$ $20 \%$ was higher than baseline $\mathrm{pH}$ value and early change in both arterial blood $\mathrm{pH}$ and partial $\mathrm{PCO}_{2}$ following the initiation of NIV (area under the curve [AUC] was 0.84, $0.51,0.56$, and 0.54 , respectively; $p<0.0001$ ) [126].

\section{Main take home messages}

NIMV represents the main treatment for hypercapnic ARF patients with associated respiratory acidosis. Although the HFNC oxygen therapy is able to reduce the level of hypercapnia, the use in clinical practice appears controversial and not clear due to very limited studies. At the moment a cautious approach appears motivated.

\section{Unmet needs or future clinical research}

In AECOPD patients with moderate respiratory acidosis ( $\mathrm{pH}$ between 7.35 and 7.25) prospective randomized noninferiority trials considering HFNC oxygen therapy versus NIMV are ongoing $[127,128]$ with the aim to evaluate physiological [128] or clinical (endotracheal intubation prevention) [127] effects. Future studies need to clarify when or not HFNC may be proposed as a valid alternative choise for hypercapnic ARF patients and when could be better to swich to NIMV; such as endotracheal intubation for NIMV, a delay in treatment with HFNC could have a worse outcome in AECOPD patient.

\section{Pulmonary rehabilitation}

Pulmonary rehabilitation (PR) is a comprehensive nonpharmacological treatment to which COPD is most susceptible to improvements [129]. Exercise capacity and symptoms such as dyspnea and quality of life represent the main outcomes [129-132]. PR benefits COPD patients with different functional stages [133] and different phenotypes [134], the elderly [135], those with fewer or more comorbidities [136, 137], those with physical frailty [138], and even cachectic patients [139]. Historically, PR has been proposed for COPD patients in a stable phase of disease [129] and just after an AECOPD exacerbation [140], but not during AECOPD due to safety-related aspects. However, recent evidence also demonstrates the efficacy of a PR program for severe hospitalized AECOPD patients [141-147].

AECOPD reduces the physical activity of patients [148]. Hospitalization due to AECOPD leads to physical 
and functional impairment [149] with loss of quadriceps muscle strength [150], exercise tolerance [151] and health status [152]. The role of PR during hospitalization may thus be justified.

The first evidence on PR in respiratory acute patients was published by Trooster and colleagues in 2010 [141] and opened up new possibilities for early rehabilitation treatment [153]. The authors demonstrated, in a randomized trial on 40 severe AECOPD, that an additional resistance training program is feasible and safe during hospitalization and can prevent muscle deterioration [141]. Patients who received training showed an improvement in quadriceps force and walking capacity (documented by 6MWD [6-min walking distance]) at discharge; improvements were also documented at 1 month of follow up [141]. Similar and very recent studies on severe hospitalized AECOPD patients [142] and frail-elderly patients [143] suggest improvements in lower-limb muscle strength [142, 143], balance [143], exercise capacity [142, 143], and quality of life [142]. Feasibility studies on neuromuscular electrical stimulation (NMES) showed improvements in quadriceps muscle strength [154, 155]. Thus, all studies proposed for severe hospitalized AECOPD patients have found rehabilitative intervention to be feasible and safe [142-146, 154, 155]. At this point in time, only one randomized trial [156] aimed at reducing the readmission rate at 12 months (outcome failed) has documented a higher mortality risk in the treated group (OR 1.74, 95\% CI 1.05 to 2.88, $p=0.03$ ) [156]; however, the difference in mortality began $>5$ months after the completion of the intervention and was not related to the early rehabilitation intervention [157].

\section{Main take home messages}

In hospitalized AECOPD an early PR program has proved to be feasibility and safe. However, there are still few evidences to recommend this treatment for patients admitted to hospital.

\section{Unmet needs or future clinical research}

Prospective studies are needed to identify the PR interventions providing the greatest benefits.

\section{Summary of recommendations or suggestions}

Table 4 reports the summary of recommendations or suggestions from the GOLD document, NICE guidelines and ERS/ATS guidelines about the pharmacological and non-pharmacological treatments used in the management of a severe AECOPD.

\section{Non-conventional drugs}

Some non-conventional approaches have been proposed in severe AECOPD [158-160].
In a randomized double-blinded clinical trial the effect of nebulized furosemide ( $40 \mathrm{mg}$ ) as an adjunct to conventional treatment has been tested in the emergency department on 100 AECOPD patients [158]. Changes in dyspnea perception, $\mathrm{FEV}_{1}$, arterial blood gas variables, blood pressure, breathing frequency, and heart rate at baseline and at $1 \mathrm{~h}$ were the study measurements. In both groups (nebulized furosemide and saline) all measured variables were improved at $1 \mathrm{~h}$, although $\mathrm{FEV}_{1}$, dyspnea score, $\mathrm{PaO}_{2}, \mathrm{pH}$, blood pressure, breathing frequency, heart rate, improved significantly more in the furosemide group. Patients presenting a lower $\mathrm{FEV}_{1}$ on admission had more benefit from furosemide than those who had a higher baseline $\mathrm{FEV}_{1}$ [158].

Another randomized, placebo-control, double-blind, crossover trial [159] enrolling 24 AECOPD patients has tested the effect of magnesium sulfate (1.5 $\mathrm{g}$ intravenous for $20 \mathrm{~min}) . \mathrm{FEV}_{1}$ was measured after 15, 30, and 45 min of magnesium sulfate or placebo administration and after a dose of $400 \mu \mathrm{g}$ of salbutamol. In term of $\mathrm{FEV}_{1}$ after 15, 30, and 45 min no differences were found between groups, while the $\mathrm{FEV}_{1}$ measured after salbutamol found significantly greater increases in the magnesium sulfate group in comparison to placebo $(+0.185 \mathrm{~L}$ and $+0.081 \mathrm{~L} ; p=0.004$, respectively) [159]. In conclusion, the magnesium sulfate has no bronchodilatation effect in AECOPD patients, although it enhances the bronchodilating effect of salbutamol [159].

The last randomized double-blind, placebo-controlled, parallel group trial has evaluated the effect of oral zileuton (a 5-lipoxygenase inhibitor having an effect on leukotrienes) at the dose of $2400 \mathrm{mg}$ daily for 14 days [160]. The primary outcome was the length of hospital stay, while the secondary ones were treatment failure and biomarkers of leukotriene production. There was no difference in the length of hospital stay (3.75 days versus 3.86 days, $p=0.39$ for zileuton and placebo groups, respectively) and treatment failure (23\% versus $27 \%, p=$ 0.63 for zileuton and placebo groups, respectively), despite a decline in urinary leukotrienes levels in the zileuton-treated group at 24 and $72 \mathrm{~h} \mathrm{[160].} \mathrm{Due} \mathrm{to} \mathrm{the}$ slow recruitment the study has been stopped before the enrollement target and for this reason the sample size analysed may have been insufficient for the meaningful.

\section{Conclusion}

Several treatments exist for severe AECOPD patients requiring hospitalization. However, some treatments lack strong evidence. Strong evidence currently exists for steroids and NIMV, in patients admitted with a hypercapnic acute respiratory failure and respiratory acidosis. HFNC oxygen therapy needs further evidences to be suggested. Concerning the use of antibiotics, while many benefits have been reported for ICU patients, there is a 
Table 4 Summary of recommendations or suggestions from the GOLD document, NICE guidelines and ERS/ATS guidelines about management of severe AECOPD

\begin{tabular}{|c|c|c|c|}
\hline $\begin{array}{l}\text { In-hospital AECOPD } \\
\text { treatments }\end{array}$ & GOLD document & NICE guidelines & ERS/ATS guidelines \\
\hline Bronchodilators & $\begin{array}{l}\text { SABA with or without short-acting anticholinergics } \\
\text { are the initial bronchodilators recommended. It is } \\
\text { recommended that patients do not receive } \\
\text { continuous nebulization, but use the MDI inhaler. } \\
\text { It is recommended continuining long-acting } \\
\text { bronchodilators or starting as soon as possible }\end{array}$ & $\begin{array}{l}\text { Increased doses of short-acting } \\
\text { bronchodilators are suggested. } \\
\text { Both nebulisers and } \\
\text { hand-held inhalers can be } \\
\text { used to administer inhaled } \\
\text { therapy. Patients should be } \\
\text { changed to hand-held } \\
\text { inhalers as soon as their } \\
\text { condition has stabilised }\end{array}$ & It is not reported \\
\hline Steroids & $\begin{array}{l}\text { Prednisone } 40 \mathrm{mg} \text { per day for } 5 \text { days is } \\
\text { recommended. Therapy with oral prednisolone } \\
\text { is equally effective to intravenous administration }\end{array}$ & $\begin{array}{l}\text { Prednisolone } 30 \mathrm{mg} \text { orally } \\
\text { should be prescribed for } 7 \\
\text { to } 14 \text { days }\end{array}$ & $\begin{array}{l}\text { Suggested oral administration } \\
\text { (conditional recommendation, } \\
\text { low quality of evidence) }\end{array}$ \\
\hline Antibiotics & $\begin{array}{l}\text { They should be given in patients who have: all three } \\
\text { symptoms (increase in dyspnea, sputum volume, } \\
\text { and sputum purulence); increased sputum purulence; } \\
\text { required mechanical ventilation. The recommended } \\
\text { length of therapy is } 5 \text { to } 7 \text { days }\end{array}$ & $\begin{array}{l}\text { Antibiotics should be used to } \\
\text { treat exacerbations of COPD } \\
\text { associated with a history of } \\
\text { more purulent sputum }\end{array}$ & $\begin{array}{l}\text { It is not reported for hospitalized } \\
\text { patients with AECOPD }\end{array}$ \\
\hline Oxygen therapy & $\begin{array}{l}\text { If necessary, oxygen should be given to keep the } \\
\mathrm{SaO}_{2} \text { within the individualised target range }\end{array}$ & $\begin{array}{l}\text { Supplemental oxygen should } \\
\text { be titrated to improve } \\
\text { hypoxemia, with a target } \\
\mathrm{SaO}_{2} \text { of } 88 \text { to } 92 \%\end{array}$ & It is not reported \\
\hline HFNC & $\begin{array}{l}\text { In patients with hypoxemic ARF it may be an alternative } \\
\text { to standard oxygen therapy or NIMV. There is a need } \\
\text { for well-designed, randomized, multicenter trials to } \\
\text { study the effects of HFNC in hypoxemic/hypercapnic } \\
\text { ARF. }\end{array}$ & It is not reported & It is not reported \\
\hline NIMV & $\begin{array}{l}\text { It is indicated in patients with respiratory acidosis or } \\
\text { severe dyspnoea with clinical signs suggestive of } \\
\text { respiratory muscle fatigue, increased work of breathing, } \\
\text { or persistent hypoxemia despite supplemental oxygen } \\
\text { therapy }\end{array}$ & $\begin{array}{l}\text { It should be used as the } \\
\text { treatment of choice for } \\
\text { persistent hypercapnic } \\
\text { ventilatory failure during } \\
\text { exacerbations despite optimal } \\
\text { medical therapy }\end{array}$ & $\begin{array}{l}\text { It is recommended for patients } \\
\text { with acute or acute-on-chronic } \\
\text { hypercapnic respiratory failure } \\
\text { (strong recommendation, low } \\
\text { quality of evidence) }\end{array}$ \\
\hline $\begin{array}{l}\text { Pulmonary } \\
\text { rehabilitation }\end{array}$ & It is not reported for hospitalized patients with AECOPD & $\begin{array}{l}\text { It is not reported for } \\
\text { hospitalized patients with } \\
\text { AECOPD }\end{array}$ & $\begin{array}{l}\text { It is suggested not initiating } \\
\text { during hospitalisation (conditional } \\
\text { recommendation, very low quality } \\
\text { of evidence) }\end{array}$ \\
\hline
\end{tabular}

Reported from references $[1,9,10]$

Abbreviations: SABA indicates short-acting $\beta_{2}$ agonists, $M D I$ metered-dose inhaler, HFNC high flow nasal cannulae oxygen therapy, NIMV non-invasive mechanical ventilation, $\mathrm{SaO}_{2}$ oxygen saturation, $A R F$ acute respiratory failure

lack of evidence on the preferred drug and optimal duration of treatment for hospitalized patients. Early rehabilitation, if associated with standard treatment of patients, should be proposed due to its feasibility and safety: we should apply the rule that "more is better". There are currently few options involving new drugs or new applications of existing drugs.

\section{Abbreviations}

AECOPD: Acute exacerbation of chronic obstructive pulmonary disease; ARF: Acute respiratory failure; COPD: Chronic obstructive pulmonary disease; CRP: C-reactive protein; DD: Diaphragmatic dysfunction; DPI: Dry powder inhalers; $\mathrm{FEV}_{1}$ : Forced expiratory volume in the $1^{\text {st }}$ second; FVC: Forced vital capacity; GNEB: Gram-negative enteric bacilli; HFNC: High flow nasal cannulae; ICU: Intensive care unit; IQR: Interquartile range; ITT: Intention-totreat; LABA: Long-acting $\beta_{2}$ agonists; MDI: Metered-dose inhaler; MRCT: Microorganisms resistant to conventional treatment;

MSCT: Microorganisms sensitive to conventional treatment; NIMV: Noninvasive mechanical ventilation; OR: Odds ratio; $\mathrm{PaO}_{2}$ : Partial arterial oxygen pressure; PP: Per-protocol; SABA: Short-acting $\beta_{2}$ agonists
Availability of data and materials

Only on written request to Authors.

\section{Authors' contributions}

Drafting the work or revising it critically for important intellectual content: EC, EB, Al, AT. Final approval of the version submitted for publication: AT. All authors read and approved the final version of the manuscript.

Ethics approval and consent to participate

Not applicable, as the article is a narrative review, based on a search on Medline.

\section{Consent for publication}

Not applicable, as the article is a narrative review, based on a search on Medline.

\section{Competing interests}

The authors report no conflicts of interest about this manuscript. AT is a member of the Editorial Board of Multidisciplinary Respiratory Medicine. 


\section{Publisher's Note}

Springer Nature remains neutral with regard to jurisdictional claims in published maps and institutional affiliations.

\section{Author details \\ 'Department of Medicine and Surgery, Respiratory Disease and Lung Function Unit, University of Parma, Parma, Italy. ${ }^{2}$ Pneumology Department, Clinic Institute of Thorax, Hospital Clinic of Barcelona - Institut d'Investigacions Biomèdiques August Pi i Sunyer (IDIBAPS), University of Barcelona, Barcelona, Spain.}

\section{Received: 29 June 2018 Accepted: 15 August 2018}

Published online: 02 October 2018

\section{References}

1. Global Strategy for the Diagnosis, Management, and Prevention of Chronic Obstructive Pulmonary Disease. 2018 Report. Available at https://goldcopd. org/. Accessed 30 July 2018.

2. White AJ, Gompertz S, Stockley RA. Chronic obstructive pulmonary disease. 6: the aetiology of exacerbations of chronic obstructive pulmonary disease. Thorax. 2003;58:73-80.

3. Hurst JR, Donaldson GC, Perera WR, Wilkinson TM, Bilello JA, Hagan GW et al. Use of plasma biomarkers at exacerbation of chronic obstructive pulmonary disease. Am J Respir Crit Care Med. 2006;174:867-74.

4. Spencer $\mathrm{S}$, Jones PW. Time course of recovery of health status following an infective exacerbation of chronic bronchitis. Thorax. 2003;58(7):589-93.

5. Suissa S, Dell'Aniello S, Ernst P. Long-term natural history of chronic obstructive pulmonary disease: severe exacerbations and mortality. Thorax. 2012;67(11):957-63.

6. Pauwels R, Calverley P, Buist AS, Rennard S, Fukuchi Y, Stahl E, et al. COPD exacerbations: the importance of a standard definition. Respir Med. 2004; 98(2):99-107.

7. Montes de Oca M, Laucho-Contreras ME. Is It Time to Change the Definition of Acute Exacerbation of Chronic Obstructive Pulmornary Disease? What Do We Need to Add? Med Sci (Basel). 2018;6(2) https://doi.org/10.3390/ medsci6020050

8. Anthonisen NR, Manfreda J, Warren CP, Hershfield ES, Harding GK, Nelson NA. Antibiotic therapy in exacerbations of chronic obstructive pulmonary disease. Ann Intern Med. 1987:106:196-204.

9. National Institute for Health and Care Excellence. Chronic obstructive pulmonary disease in over 16s: diagnosis and management. 2010. Available at https://www.nice.org.uk/guidance/CG101. Accessed 30 July 2018.

10. Wedzicha JA, Miravitlles M, Hurst JR, Calverley PM, Albert RK, Anzueto A, et al. Management of COPD exacerbations: a European Respiratory Society/ American Thoracic Society guideline. Eur Respir J. 2017;49(3) https://doi.org/ 10.1183/13993003.00791-2016.

11. Noell G, Cosío BG, Faner R, Monsó E, Peces-Barba G, de Diego A, et al. Multilevel differential network analysis of COPD exacerbations. Eur Respir J. 2017; 50(3) https://doi.org/10.1183/13993003.00075-2017.

12. Celli BR. Dissecting COPD exacerbations: time to rethink our definition. Eur Respir J. 2017;50(3) https://doi.org/10.1183/13993003.01432-2017.

13. Celli BR, Barnes PJ. Exacerbations of chronic obstructive pulmonary disease. Eur Respir J. 2007:29(6):1224-38.

14. Antoniu SA, Carone M. Hospitalizations for chronic obstructive pulmonary disease exacerbations and their impact on disease and subsequent morbidity and mortality. Expert Rev Pharmacoecon Outcomes Res. 2013; 13(2):187-9.

15. Garcia-Aymerich J, Serra Pons I, Mannino DM, Maas AK, Miller DP, Davis KJ. Lung function impairment, COPD hospitalisations and subsequent mortality. Thorax. 2011;66:585-59

16. Kilic H, Kokturk N, Sari G, Cakır M. Do females behave differently in COPD exacerbation? Int J Chron Obstruct Pulmon Dis. 2015;10:823-30.

17. Sadatsafavi M, Xie H, Etminan M, Johnson K, FitzGerald JM. Canadian Respiratory Research Network. The association between previous and future severe exacerbations of chronic obstructive pulmonary disease: Updating the literature using robust statistical methodology. PLoS One. 2018;13(1): e0191243.

18. Hurst JR, Vestbo J, Anzueto A, Locantore N, Müllerova $H$, Tal-Singer $R$, et al. Evaluation of COPD longitudinally to identify predictive surrogate endpoints (ECLIPSE) investigators. Susceptibility to exacerbation in chronic obstructive pulmonary disease. N Engl J Med. 2010;363(12):1128-38.
19. Müllerova H, Maselli DJ, Locantore N, Vestbo J, Hurst JR, Wedzicha JA, et al. Hospitalized exacerbations of COPD: risk factors and outcomes in the ECLIPSE cohort. Chest. 2015;147(4):999-1007.

20. Santibáñez M, Garrastazu R, Ruiz-Nuñez M, Helquera JM, Arenal S, Bonnardeux $C$, et al. Predictors of hospitalized exacerbations and mortality in chronic obstructive pulmonary disease. PLoS One. 2016; 11(6):e0158727.

21. Singanayagam A, Schembri S, Chalmers JD. Predictors of mortality in hospitalized adults with acute exacerbation of chronic obstructive pulmonary disease. Ann Am Thorac Soc. 2013;10(2):81-9.

22. Jeong $\mathrm{SH}$, Lee $\mathrm{H}$, Carriere $\mathrm{KC}$, Shin $\mathrm{SH}$, Moon SM, Jeong BH, et al. Comorbidity as a contributor to frequent severe acute exacerbation in COPD patients. Int J Chron Obstruct Pulmon Dis. 2016:11:1857-65.

23. Hoogendoorn M, Hoogenveen RT, Rutten-van Mölken MP, Vestbo J, Feenstra TL. Case fatality of COPD exacerbations: a meta-analysis and statistical modelling approach. Eur Respir J. 2011;37(3):508-15.

24. Chalela R, González-García JG, Chillarón JJ, Valera-Hernández L, MontoyaRangel C, Badenes D, et al. Impact of hyponatremia on mortality and morbidity in patients with COPD exacerbations. Respir Med. 2016;117:237-42

25. Chen CW, Chen YY, Lu CL, Chen SC, Chen YJ, Lin MS, et al. Severe hypoalbuminemia is a strong independent risk factor for acute respiratory failure in COPD: a nationwide cohort study. Int J Chron Obstruct Pulmon Dis. 2015;10:1147-54.

26. Aliyali M, Mehravaran H, Abedi S, Sharifpour A, Yazdani CJ. Impact of comorbid ischemic heart disease on short-term outcomes of patients hospitalized for acute exacerbations of COPD. Tanaffos. 2015;14(3):165-71.

27. Fabbian F, De Giorgi A, Manfredini F, Lamberti N, Forcellini S, Storari A, et al. Impact of renal dysfunction on in-hospital mortality of patients with severe chronic obstructive pulmonary disease: a single-center Italian study. Int Urol Nephrol. 2016:48(7):1121-7.

28. Wells JM, Morrison JB, Bhatt SP, Nath H, Dransfield MT. Pulmonary artery enlargement is associated with cardiac injury during severe exacerbations of COPD. Chest. 2016;149(5):1197-204

29. Mantero M, Rogliani P, Di Pasquale M, Polverino E, Crisafulli E, Guerrero M, et al. Acute exacerbations of COPD: risk factors for failure and relapse. Int J Chron Obstruct Pulmon Dis. 2017:12:2687-93.

30. Prieto-Centurion V, Markos MA, Ramey NI, Gussin HA, Nyenhuis SM, Joo MJ, et al. Interventions to reduce rehospitalizations after chronic obstructive pulmonary disease exacerbations. A systematic review. Ann Am Thorac Soc. 2014;11:417-24.

31. Sharif R, Parekh TM, Pierson KS, Kuo YF, Sharma G. Predictors of early readmission among patients 40 to 64 years of age hospitalized for chronic obstructive pulmonary disease. Ann Am Thorac Soc. 2014;11:685-94.

32. Crisafulli E, Torres A, Huerta A, Méndez R, Guerrero M, Martinez R, et al. Creactive protein at discharge, diabetes mellitus and $\geq 1$ hospitalization during previous year predict early readmission in patients with acute exacerbation of chronic obstructive pulmonary disease. COPD. 2015:12(3): 306-14

33. Crisafulli E, Ortega S, Torres A. Predictors of readmission in a period of 30 days or less in acute exacerbation of chronic obstructive pulmonary disease. Clin Pulm Med 2015:22(4):172-6.

34. Guerrero M, Crisafulli E, Liapikou A, Huerta A, Gabarrús A, Chetta A, et al. Readmission for acute exacerbation within 30 days of discharge is associated with a subsequent progressive increase in mortality risk in COPD patients: a long-term observational study. PLoS One. 2016:11(3):e0150737.

35. Crisafulli $E$, Guerrero M, Chetta A, Torres A. Readmission in COPD patients: should we consider it a marker of quality of care or a marker of a more severe disease with a worse prognosis? Eur Respir J. 2016;48(1):279-81.

36. Calverley PM, Anzueto AR, Dusser D, Mueller A, Metzdorf N, Wise RA. Treatment of exacerbations as a predictor of subsequent outcomes in patients with COPD. Int J Chron Obstruct Pulmon Dis. 2018;13:1297-308.

37. Crisafulli E, Torres A, Huerta A, Guerrero M, Gabarrús A, Gimeno A, et al. Predicting in-hospital treatment failure $(\leq 7$ days) in patients with COPD exacerbation using antibiotics and systemic steroids. COPD. 2016:13(1):82-92.

38. Kocks JW, van den Berg JW, Kerstjens HA, Uil SM, Vonk JM, de Jong YP, et al. Day-to-day measurement of patient-reported outcomes in exacerbations of chronic obstructive pulmonary disease. Int J Chron Obstruct Pulmon Dis. 2013:8:273-86

39. Amin AN, Bollu V, Stensland MD, Netzer L, Ganapathy V. Treatment patterns for patients hospitalized with chronic obstructive pulmonary disease. Am J Health Syst Pharm. 2018;75(6):359-66. 
40. Turner MO, Patel A, Ginsburg S, FitzGerald JM. Bronchodilator delivery in acute airflow obstruction. A meta-analysis Arch Intern Med. 1997;157(15): $1736-44$.

41. van Geffen WH, Douma WR, Slebos DJ, Kerstjens HA. Bronchodilators delivered by nebuliser versus pMDI with spacer or DPI for exacerbations of COPD. Cochrane Database Syst Rev. 2016;8:CD011826.

42. Papaioannou Al, Herodotou Y, Tomos I, Apollonatou V, Verykokou G, Papathanasiou $E$, et al. Ability of using different dry powder inhalers during COPD exacerbations. Pulm Pharmacol Ther. 2018;48:211-6.

43. Cazzola M, Matera MG. Long-acting $\beta_{2}$ agonists as potential option in the treatment of acute exacerbations of COPD. Pulm Pharmacol Ther. 2003;16: 197-201.

44. Bourbeau J, Sedeno MF, Metz K, Li PZ, Pinto L. Early COPD exacerbation treatment with combination of ICS and LABA for patients presenting with mild-to-moderate worsening of dyspnea. COPD. 2016;13(4):439-47.

45. Rogliani P, Ora J, Ciaprini C, Senis L, Stirpe E, Cazzola E. Effect of indacaterol on arterial blood gases in patients suffering from acute exacerbation of COPD. Respir Med. 2014;108:307-13.

46. Segreti A, Fiori $E$, Calzetta L, Sabatini M, Segreti V, Rogliani $P$, et al. The effect of indacaterol during an acute exacerbation of COPD. Pulm Pharmacol Ther. 2013;26:630-4

47. Wedzicha JA, Banerji D, Chapman KR, Vestbo J, Roche N, Ayers RT, et al. FLAME investigators. Indacaterol-Glycopyrronium versus salmeterolfluticasone for COPD. N Engl J Med. 2016;374(23):2222-34.

48. Davies L, Angus RM, Calverley PM. Oral corticosteroids in patients admitted to hospital with exacerbations of chronic obstructive pulmonary disease: a prospective randomised controlled trial. Lancet. 1999;354(9177):456-60.

49. Niewoehner DE, Erbland ML, Deupree RH, Collins D, Gross NJ, Light RW, et al. Effect of systemic glucocorticoids on exacerbations of chronic obstructive pulmonary disease. Department of veterans affairs cooperative study group. N Engl J Med. 1999;340(25):1941-7.

50. Aaron SD, Vandemheen KL, Hebert P, Dales R, Stiell IG, Ahuja J, et al Outpatient oral prednisone after emergency treatment of chronic obstructive pulmonary disease. N Engl J Med. 2003;348(26):2618-25.

51. Alía I, de la Cal MA, Esteban A, Abella A, Ferrer R, Molina FJ, et al. Efficacy of corticosteroid therapy in patients with an acute exacerbation of chronic obstructive pulmonary disease receiving ventilatory support. Arch Intern Med. 2011;171(21):1939-46.

52. Leuppi JD, Schuetz $P$, Bingisser $R$, Bodmer $M$, Briel $M$, Drescher $T$, et al. Short-term vs conventional glucocorticoid therapy in acute exacerbations of chronic obstructive pulmonary disease: the REDUCE randomized clinical trial. JAMA. 2013;309(21):2223-31.

53. de Jong YP, Uil SM, Grotjohan HP, Postma DS, Kerstjens HA, van den Berg JW. Oral or IV prednisolone in the treatment of COPD exacerbations: a randomized, controlled, double-blind study. Chest. 2007;132(6):1741-7.

54. Aggarwal P, Wig N, Bhoi S. Efficacy of two corticosteroid regimens in acute exacerbation of chronic obstructive pulmonary disease. Int J Tuberc Lung Dis. 2011;15(5):687-92

55. Walters JA, Tan DJ, White CJ, Wood-Baker R. Different durations of corticosteroid therapy for exacerbations of chronic obstructive pulmonary disease. Cochrane Database Syst Rev. 2018;3:CD006897.

56. Abroug F, Ouanes-Besbes L, Fkih-Hassen M, Ouanes I, Ayed S, Dachraoui F, et al. Prednisone in COPD exacerbation requiring ventilatory support: an open-label randomised evaluation. Eur Respir J. 2014;43(3):717-24.

57. Ceviker $Y$, Sayiner A. Comparison of two systemic steroid regimens for the treatment of COPD exacerbations. Pulm Pharmacol Ther. 2014;27(2): 179-83.

58. Lindenauer PK, Pekow PS, Lahti MC, Lee Y, Benjamin EM, Rothberg MB. Association of corticosteroid dose and route of administration with risk of treatment failure in acute exacerbation of chronic obstructive pulmonary disease. JAMA. 2010;303(23):2359-67.

59. Kiser TH, Allen RR, Valuck RJ, Moss M, Vandivier RW. Outcomes associated with corticosteroid dosage in critically ill patients with acute exacerbations of chronic obstructive pulmonary disease. Am J Respir Crit Care Med. 2014; 189(9):1052-64.

60. Sayiner A, Aytemur ZA, Cirit M, Unsal I. Systemic glucocorticoids in severe exacerbations of COPD. Chest. 2001;119(3):726-30.

61. Crisafulli E, Guerrero M, Menéndez R, Huerta A, Martinez R, Gimeno A, et al. Inhaled corticosteroids do not influence the early inflammatory response and clinical presentation of hospitalized subjects with COPD exacerbation. Respir Care. 2014;59(10):1550-9.
62. Maltais F, Ostinelli J, Bourbeau J, Tonnel AB, Jacquemet N, Haddon J, et al. Comparison of nebulized budesonide and oral prednisolone with placebo in the treatment of acute exacerbations of chronic obstructive pulmonary disease: a randomized controlled trial. Am J Respir Crit Care Med. 2002; 165(5):698-703

63. Ding Z, Li X, Lu Y, Rong G, Yang R, Zhang R, et al. A randomized, controlled multicentric study of inhaled budesonide and intravenous methylprednisolone in the treatment on acute exacerbation of chronic obstructive pulmonary disease. Respir Med. 2016;121:39-47.

64. Jiang Z, Zhu L. Update on molecular mechanisms of corticosteroid resistance in chronic obstructive pulmonary disease. Pulm Pharmacol Ther. 2016:37:1-8.

65. Sethi S, Murphy TF. Infection in the pathogenesis and course of chronic obstructive pulmonary disease. N Engl J Med. 2008;359:2355-65.

66. Wedzicha JA, Seemungal TA. COPD exacerbations: defining their cause and prevention. Lancet. 2007:370:786-96.

67. Miravitlles M, Kruesmann F, Haverstock D, Perroncel R, Choudhri SH, Arvis P. Sputum colour and bacteria in chronic bronchitis exacerbations: a pooled analysis. Eur Respir J. 2012;39(6):1354-60.

68. Huerta A, Crisafulli E, Menéndez R, Martínez R, Soler N, Guerrero M, et al. Pneumonic and nonpneumonic exacerbations of COPD: inflammatory response and clinical characteristics. Chest. 2013;144(4):1134-42.

69. Soler N, Torres A, Ewig S, Gonzalez J, Celis R, El-Ebiary M, et al. Bronchial microbial patterns in severe exacerbations of chronic obstructive pulmonary disease (COPD) requiring mechanical ventilation. Am J Respir Crit Care Med. 1998;157:1498-505.

70. Estirado C, Ceccato A, Guerrero M, Huerta A, Cilloniz C, Vilaró O, et al. Microorganisms resistant to conventional antimicrobials in acute exacerbations of chronic obstructive pulmonary disease. Respir Res. 2018;19(1):119.

71. Stolz D, Christ-Crain M, Bingisser R, Leuppi J, Miedinger D, Müller C, et al. Antibiotic treatment of exacerbations of COPD: a randomized, controlled trial comparing procalcitonin-guidance with standard therapy. Chest. 2007; 131(1):9-19.

72. Schuetz P, Christ-Crain M, Thomann R, Falconnier C, Wolbers M, Widmer I, et al. Effect of procalcitonin-based guidelines vs standard guidelines on antibiotic use in lower respiratory tract infections: the ProHOSP randomized controlled trial. JAMA. 2009;302(10):1059-66.

73. Schuetz P, Wirz Y, Sager R, Christ-Crain M, Stolz D, Tamm M, et al. Procalcitonin to initiate or discontinue antibiotics in acute respiratory tract infections. Cochrane Database Syst Rev. 2017;10:CD007498.

74. Wang JX, Zhang SM, Li XH, Zhang Y, Xu ZY, Cao B. Acute exacerbations of chronic obstructive pulmonary disease with low serum procalcitonin values do not benefit from antibiotic treatment: a prospective randomized controlled trial. Int J Infect Dis. 2016;48:40-5.

75. Masterton RG, Burley CJ. Randomized, double-blind study comparing 5- and 7-day regimens of oral levofloxacin in patients with acute exacerbation of chronic bronchitis. Int J Antimicrob Agents. 2001;18(6):503-12.

76. Vollenweider DJ, Jarrett H, Steurer-Stey CA, Garcia-Aymerich J, Puhan MA. Antibiotics for exacerbations of chronic obstructive pulmonary disease. Cochrane Database Syst Rev. 2012;12:CD010257.

77. Nouira S, Marghli S, Belghith M, Besbes L, Elatrous S, Abroug F. Once daily oral ofloxacin in chronic obstructive pulmonary disease exacerbation requiring mechanical ventilation: a randomised placebo-controlled trial. Lancet. 2001;358(9298):2020-5.

78. Alonso Martínez JL, Rubio Obanos MT, Sampériz Legarre AL, Escolar Castellón F, Carrasco del Amo ME. Antibiotic treatment for acute episodes of chronic obstructive pulmonary disease. An Med Interna. 1992;9(8):377-80.

79. Pines A, Raafat H, Plucinski K, Greenfield JS, Solari M. Antibiotic regimens in severe and acute purulent exacerbations of chronic bronchitis. Br Med J. 1968;2(5607):735-8.

80. Pines A, Raafat $H$, Greenfield JS, Linsell WD, Solari ME. Antibiotic regimens in moderately ill patients with purulent exacerbations of chronic bronchitis. $\mathrm{Br}$ J Dis Chest. 1972:66(2):107-15.

81. Daniels JM, Snijders D, de Graaff CS, Vlaspolder F, Jansen HM, Boersma WG. Antibiotics in addition to systemic corticosteroids for acute exacerbations of chronic obstructive pulmonary disease. Am J Respir Crit Care Med. 2010; 181(2):150-7.

82. Nouira S, Marghli S, Besbes L, Boukef R, Daami M, Nciri N, et al. Standard versus newer antibacterial agents in the treatment of severe acute exacerbation of chronic obstructive pulmonary disease: a randomized trial of trimethoprim-sulfamethoxazole versus ciprofloxacin. Clin Infect Dis. 2010; 51(2):143-9. 
83. Austin MA, Wills KE, Blizzard L, Walters EH, Wood-Baker R. Effect of high flow oxygen on mortality in chronic obstructive pulmonary disease patients in prehospital setting: randomised controlled trial. BMJ. 2010;341:c5462.

84. Plant PK, Owen JL, Elliott MW. One year period prevalence study of respiratory acidosis in acute exacerbations of COPD: implications for the provision of non-invasive ventilation and oxygen administration. Thorax. 2000;55(7):550-4

85. Lellouche F, Bouchard PA, Roberge M, Simard S, L'Her E, Maltais F, et al. Automated oxygen titration and weaning with $\mathrm{FreeO}_{2}$ in patients with acute exacerbation of COPD: a pilot randomized trial. Int J Chron Obstruct Pulmon Dis. 2016;11:1983-90.

86. Frat JP, Coudroy R, Marjanovic N, Thille AW. High-flow nasal oxygen therapy and noninvasive ventilation in the management of acute hypoxemic respiratory failure. Ann Transl Med. 2017:5(14):297.

87. Sztrymf B, Messika J, Bertrand F, Hurel D, Leon R, Dreyfuss D, et al. Beneficial effects of humidified high flow nasal oxygen in critical care patients: a prospective pilot study. Intensive Care Med. 2011;37(11):1780-6.

88. Sztrymf B, Messika J, Mayot T, Lenglet H, Dreyfuss D, Ricard JD. Impact of high-flow nasal cannula oxygen therapy on intensive care unit patients with acute respiratory failure: a prospective observational study. J Crit Care. 2012; 27(3):324.e9-13. https://doi.org/10.1016/j.jcrc.2011.07.075.

89. Riera J, Pérez P, Cortés J, Roca O, Masclans JR, Rello J. Effect of high-flow nasal cannula and body position on end-expiratory lung volume: a cohort study using electrical impedance tomography. Respir Care. 2013;58(4):589-96.

90. Lin SM, Liu KX, Lin ZH, Lin PH. Does high-flow nasal cannula oxygen improve outcome in acute hypoxemic respiratory failure? A systematic review and meta-analysis. Respir Med. 2017;131:58-64.

91. Corley A, Rickard CM, Aitken LM, Johnston A, Barnett A, Fraser JF, et al. High-flow nasal cannulae for respiratory support in adult intensive care patients. Cochrane Database Syst Rev. 2017;5:CD010172. https://doi.org/10. 1002/14651858.CD010172.pub2.

92. Vogelsinger H, Halank M, Braun S, Wilkens H, Geiser T, Ott S, et al. Efficacy and safety of nasal high-flow oxygen in COPD patients. BMC Pulm Med. 2017;17(1):143.

93. Bräunlich J, Köhler $\mathrm{M}$, Wirtz H. Nasal highflow improves ventilation in patients with COPD. Int J Chron Obstruct Pulmon Dis. 2016;11:1077-85.

94. Pilcher J, Eastlake L, Richards M, Power S, Cripps T, Bibby S, et al. Physiological effects of titrated oxygen via nasal high-flow cannulae in COPD exacerbations: a randomized controlled cross-over trial. Respirology. 2017;22(6):1149-55.

95. Lee MK, Choi J, Park B, Kim B, Lee SJ, Kim SH, et al. High flow nasal cannulae oxygen therapy in acute-moderate hypercapnic respiratory failure. Clin Respir J. 2018;12(6):2046-56.

96. Soo Hoo GW, Esquinas AM, Karim HMR. High flow nasal cannulae versus non-invasive ventilation in moderate hypercapnic respiratory failure: different roads, same destination but doubtful equality. Clin Respir J. 2018; https://doi.org/10.1111/crj.12942. [Epub ahead of print]

97. Roberts CM, Stone RA, Buckingham RJ, Pursey NA, Lowe D. National Chronic Obstructive Pulmonary Disease Resources and outcomes project implementation group. Acidosis, non-invasive ventilation and mortality in hospitalised COPD exacerbations. Thorax. 2011;66(1):43-8.

98. Jeffrey AA, Warren PM, Flenley DC. Acute hypercapnic respiratory failure in patients with chronic obstructive lung disease: risk factors and use of guidelines for management. Thorax. 1992;47(1):34-40.

99. Brochard L, Mancebo J, Wysocki M, Lofaso F, Conti G, Rauss A, et al. Noninvasive ventilation for acute exacerbations of chronic obstructive pulmonary disease. N Engl J Med. 1995;333(13):817-22.

100. Celikel T, Sungur M, Ceyhan B, Karakurt S. Comparison of noninvasive positive pressure ventilation with standard medical therapy in hypercapnic acute respiratory failure. Chest. 1998;114(6):1636-42.

101. Thys F, Roeseler J, Reynaert M, Liistro G, Rodenstein DO. Noninvasive ventilation for acute respiratory failure: a prospective randomised placebocontrolled trial. Eur Respir J. 2002;20(3):545-55.

102. Carrera M, Marín JM, Antón A, Chiner E, Alonso ML, Masa JF, et al. A controlled trial of noninvasive ventilation for chronic obstructive pulmonary disease exacerbations. J Crit Care. 2009;24(3):473. e7-14

103. Martin TJ, Hovis JD, Costantino JP, Bierman MI, Donahoe MP, Rogers RM, et al. A randomized, prospective evaluation of noninvasive ventilation for acute respiratory failure. Am J Respir Crit Care Med. 2000;161(3 Pt 1):807-13.

104. Chandra D, Stamm JA, Taylor B, Ramos RM, Satterwhite L, Krishnan JA, et al. Outcomes of noninvasive ventilation for acute exacerbations of chronic obstructive pulmonary disease in the United States, 1998-2008. Am J Respir Crit Care Med. 2012;185(2):152-9.
105. Rochwerg B, Brochard L, Elliott MW, Hess D, Hill NS, Nava S, et al. Official ERS/ ATS clinical practice guidelines: noninvasive ventilation for acute respiratory failure. Eur Respir J. 2017;50(2). https:/doi.org/10.1183/13993003.02426-2016.

106. Lightowler JV, Wedzicha JA, Elliott MW, Ram FS. Non-invasive positive pressure ventilation to treat respiratory failure resulting from exacerbations of chronic obstructive pulmonary disease: Cochrane systematic review and meta-analysis. BMJ. 2003;326(7382):185.

107. Osadnik CR, Tee VS, Carson-Chahhoud KV, Picot J, Wedzicha JA, Smith BJ. Non-invasive ventilation for the management of acute hypercapnic respiratory failure due to exacerbation of chronic obstructive pulmonary disease. Cochrane Database Syst Rev. 2017;7:CD004104.

108. Plant PK, Owen JL, Elliott MW. Early use of non-invasive ventilation for acute exacerbations of chronic obstructive pulmonary disease on general respiratory wards: a multicentre randomised controlled trial. Lancet. 2000;355(9219):1931-5.

109. Bott J, Carroll MP, Conway JH, Keilty SE, Ward EM, Brown AM, et al. Randomised controlled trial of nasal ventilation in acute ventilatory failure due to chronic obstructive airways disease. Lancet. 1993;341(8860):1555-7.

110. Kramer N, Meyer TJ, Meharg J, Cece RD, Hill NS. Randomized, prospective trial of noninvasive positive pressure ventilation in acute respiratory failure. Am J Respir Crit Care Med. 1995;151(6):1799-806.

111. Plant PK, Owen JL, Elliott MW. Non-invasive ventilation in acute exacerbations of chronic obstructive pulmonary disease: long term survival and predictors of in-hospital outcome. Thorax. 2001;56(9):708-12.

112. Plant PK, Owen JL, Parrott S, Elliott MW. Cost effectiveness of ward based non-invasive ventilation for acute exacerbations of chronic obstructive pulmonary disease: economic analysis of randomised controlled trial. BMJ. 2003;326(7396):956.

113. Nava S, Hill N. Non-invasive ventilation in acute respiratory failure. Lancet. 2009;374(9685):250-9.

114. Nava S, Navalesi P, Gregoretti C. Interfaces and humidification for noninvasive mechanical ventilation. Respir Care. 2009;54(1):71-84

115. Pisani L, Mega C, Vaschetto R, Bellone A, Scala R, Cosentini R, et al. Oronasal mask versus helmet in acute hypercapnic respiratory failure. Eur Respir J. 2015;45(3):691-9.

116. Antonaglia V, Ferluga M, Molino R, Lucangelo U, Peratoner A, Roman-

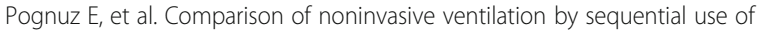
mask and helmet versus mask in acute exacerbation of chronic obstructive pulmonary disease: a preliminary study. Respiration. 2011;82(2):148-54.

117. Nicolini A, Santo M, Ferrari-Bravo M, Barlascini C. Open-mouthpiece ventilation versus nasal mask ventilation in subjects with COPD exacerbation and mild to moderate acidosis: a randomized trial. Respir Care. 2014;59(12):1825-31.

118. Di Marco F, Centanni S, Bellone A, Messinesi G, Pesci A, Scala R, et al. Optimization of ventilator setting by flow and pressure waveforms analysis during noninvasive ventilation for acute exacerbations of COPD: a multicentric randomized controlled trial. Crit Care. 2011;15(6):R283.

119. Jaber S, Fodil R, Carlucci A, Boussarsar M, Pigeot J, Lemaire F, et al. Noninvasive ventilation with helium-oxygen in acute exacerbations of chronic obstructive pulmonary disease. Am J Respir Crit Care Med. 2000;161(4 Pt 1):1191-200.

120. Jolliet P, Ouanes-Besbes L, Abroug F, Ben Khelil J, Besbes M, Garnero A, et al. A multicenter randomized trial assessing the efficacy of helium/ oxygen in severe exacerbations of chronic obstructive pulmonary disease. Am J Respir Crit Care Med. 2017;195(7):871-80.

121. Abroug F, Ouanes-Besbes L, Hammouda Z, Benabidallah S, Dachraoui F, Ouanes I, et al. Noninvasive ventilation with helium-oxygen mixture in hypercapnic COPD exacerbation: aggregate meta-analysis of randomized controlled trials. Ann Intensive Care. 2017;7(1):59.

122. Ferrer $M$, Torres $A$. Noninvasive ventilation with helium/oxygen in chronic obstructive pulmonary disease exacerbations. When physiologic improvement does not translate into clinical benefit. Am J Respir Crit Care Med. 2017;195(7):843-4.

123. Maggiore SM, Richard JC, Abroug F, Diehl JL, Antonelli M, Sauder P, et al. A multicenter, randomized trial of noninvasive ventilation with helium-oxygen mixture in exacerbations of chronic obstructive lung disease. Crit Care Med. 2010;38(1):145-51.

124. Ambrosino N, Foglio K, Rubini F, Clini E, Nava S, Vitacca M. Non-invasive mechanical ventilation in acute respiratory failure due to chronic obstructive pulmonary disease: correlates for success. Thorax. 1995;50(7):755-7.

125. Confalonieri M, Garuti G, Cattaruzza MS, Osborn JF, Antonelli M, Conti G, et al. Italian noninvasive positive pressure ventilation (NPPV) study group. A chart of failure risk for noninvasive ventilation in patients with COPD exacerbation. Eur Respir J. 2005;25(2):348-55. 
126. Marchioni A, Castaniere I, Tonelli R, Fantini R, Fontana M, Tabbì L, et al. Ultrasound-assessed diaphragmatic impairment is a predictor of outcomes in patients with acute exacerbation of chronic obstructive pulmonary disease undergoing noninvasive ventilation. Crit Care. 2018;22(1):109.

127. https://clinicaltrials.gov/ct2/show/NCT03014869?term=NCT03014869\&rank= 1. Accessed 30 July 2018.

128. https://clinicaltrials.gov/ct2/show/NCT03033251?term=NCT03033251\&rank= 1. Accessed 30 July 2018

129. Spruit MA, Singh SJ, Garvey C, ZuWallack R, Nici L, Rochester C, et al. An official American Thoracic Society/European Respiratory Society statement: key concepts and advances in pulmonary rehabilitation. Am J Respir Crit Care Med. 2013;188(8):e13-64.

130. Clini EM, Crisafulli E. Exercise capacity as a pulmonary rehabilitation outcome. Respiration. 2009;77(2):121-8.

131. Crisafulli E, Clini EM. Measures of dyspnea in pulmonary rehabilitation. Multidiscip Respir Med. 2010;5(3):202-10.

132. Garrod R, Malerba M, Crisafulli E. Determinants of success. Eur Respir J. 2011; 38(5):1215-8.

133. Vogiatzis I, Terzis G, Stratakos G, Cherouveim E, Athanasopoulos D, Spetsioti $\mathrm{S}$, et al. Effect of pulmonary rehabilitation on peripheral muscle fiber remodeling in patients with COPD in GOLD stages II to IV. Chest. 2011; 140(3):744-52.

134. Crisafulli E, Venturelli E, Biscione G, Vagheggini G, lattoni A, Lucic S, et al. Exercise performance after standard rehabilitation in COPD patients with lung hyperinflation. Intern Emerg Med. 2014;9(1):23-31.

135. Crisafulli E, Morandi A, Olivini A, Malerba M, Clini EM. Rehabilitation and supportive therapy in elderly patients with chronic obstructive pulmonary disease. Eur J Intern Med. 2014;25(4):329-35.

136. Crisafulli E, Costi S, Luppi F, Cirelli G, Cilione C, Coletti O, et al. Role of comorbidities in a cohort of patients with COPD undergoing pulmonary rehabilitation. Thorax. 2008;63(6):487-92.

137. Crisafulli E, Gorgone P, Vagaggini B, Pagani M, Rossi G, Costa F, et al. Efficacy of standard rehabilitation in COPD outpatients with comorbidities. Eur Respir J. 2010;36(5):1042-8.

138. Maddocks M, Kon SS, Canavan JL, Jones SE, Nolan CM, Labey A, et al. Physical frailty and pulmonary rehabilitation in COPD: a prospective cohort study. Thorax. 2016;71(11):988-95.

139. Vogiatzis I, Simoes DC, Stratakos G, Kourepini E, Terzis G, Manta P, et al. Effect of pulmonary rehabilitation on muscle remodelling in cachectic patients with COPD. Eur Respir J. 2010;36(2):301-10.

140. Clini EM, Crisafulli E, Costi S, Rossi G, Lorenzi C, Fabbri LM, et al. Effects of early inpatient rehabilitation after acute exacerbation of COPD. Respir Med. 2009;103(10):1526-31.

141. Troosters T, Probst VS, Crul T, Pitta F, Gayan-Ramirez G, Decramer M, et al. Resistance training prevents deterioration in quadriceps muscle function during acute exacerbations of chronic obstructive pulmonary disease. Am J Respir Crit Care Med. 2010;181(10):1072-7.

142. Borges RC, Carvalho CR. Impact of resistance training in chronic obstructive pulmonary disease patients during periods of acute exacerbation. Arch Phys Med Rehabil. 2014;95(9):1638-45.

143. Torres-Sánchez I, Valenza MC, Cabrera-Martos I, López-Torres I, BenítezFeliponi Á, Conde-Valero A. Effects of an exercise intervention in frail older patients with chronic obstructive pulmonary disease hospitalized due to an exacerbation: a randomized controlled trial. COPD. 2017;14(1):37-42.

144. Eaton T, Young P, Fergusson W, Moodie L, Zeng I, O'Kane F, et al. Does early pulmonary rehabilitation reduce acute health-care utilization in COPD patients admitted with an exacerbation? A randomized controlled study. Respirology. 2009;14(2):230-8.

145. He M, Yu S, Wang L, Lv H, Qiu Z. Efficiency and safety of pulmonary rehabilitation in acute exacerbation of chronic obstructive pulmonary disease. Med Sci Monit. 2015;21:806-12.

146. Tang CY, Blackstock FC, Clarence M, Taylor NF. Early rehabilitation exercise program for inpatients during an acute exacerbation of chronic obstructive pulmonary disease: a randomized controlled trial. J Cardiopulm Rehabil Prev. 2012;32(3):163-9.

147. Clini $E$, Venturelli $E$, Crisafulli E. Rehabilitation in COPD patients admitted for exacerbation. Pneumonol Alergol Pol. 2011;79(2):116-20.

148. Alahmari AD, Patel AR, Kowlessar BS, Mackay AJ, Singh R, Wedzicha JA, et al. Daily activity during stability and exacerbation of chronic obstructive pulmonary disease. BMC Pulm Med. 2014;14:98.
149. Torres-Sánchez I, Cabrera-Martos I, Díaz-Pelegrina A, Valenza-Demet G, Moreno-Ramírez MP, Valenza MC. Physical and functional impairment during and after hospitalization in subjects with severe COPD exacerbation. Respir Care. 2017:62(2):209-14.

150. Spruit MA, Gosselink R, Troosters T, Kasran A, Gayan-Ramirez G, Bogaerts P, et al. Muscle force during an acute exacerbation in hospitalised patients with COPD and its relationship with CXCL8 and IGF-I. Thorax. 2003;58(9): 752-6.

151. Carr SJ, Hill K, Brooks D, Goldstein RS. Pulmonary rehabilitation after acute exacerbation of chronic obstructive pulmonary disease in patients who previously completed a pulmonary rehabilitation program. J Cardiopulm Rehabil Prev. 2009;29(5):318-24.

152. Miravitlles M, Ferrer M, Pont A, Zalacain R, Alvarez-Sala JL, Masa F, et al. Effect of exacerbations on quality of life in patients with chronic obstructive pulmonary disease: a 2 year follow up study. Thorax. 2004;59(5):387-95.

153. Clini E, Roversi $P$, Crisafulli E. Early rehabilitation: much better than nothing. Am J Respir Crit Care Med. 2010;181(10):1016-7.

154. Chaplin EJ, Houchen L, Greening NJ, Harvey-Dunstan T, Morgan MD, Steiner MC, et al. Neuromuscular stimulation of quadriceps in patients hospitalised during an exacerbation of COPD: a comparison of low $(35 \mathrm{~Hz})$ and high $(50$ Hz) frequencies. Physiother Res Int. 2013;18(3):148-56.

155. Giavedoni S, Deans A, McCaughey P, Drost E, MacNee W, Rabinovich RA. Neuromuscular electrical stimulation prevents muscle function deterioration in exacerbated COPD: a pilot study. Respir Med. 2012;106(10):1429-34.

156. Greening NJ, Williams JE, Hussain SF, Harvey-Dunstan TC, Bankart MJ, Chaplin EJ, et al. An early rehabilitation intervention to enhance recovery during hospital admission for an exacerbation of chronic respiratory disease: randomised controlled trial. BMJ. 2014;349:g4315.

157. Spruit MA, Singh SJ, Rochester CL, Greening NJ, Franssen FME, Pitta F, et al. Pulmonary rehabilitation for patients with COPD during and after an exacerbation-related hospitalisation: back to the future? Eur Respir J. 2018; 51:1701312.

158. Sheikh Motahar Vahedi H, Mahshidfar B, Rabiee H, Saadat S, Shokoohi H, Chardoli $M$, et al. The adjunctive effect of nebulized furosemide in COPD exacerbation: a randomized controlled clinical trial. Respir Care. 2013;58(11): 1873-7.

159. Abreu González J, Hernández García C, Abreu González P, Martín García C, Jiménez A. Effect of intravenous magnesium sulfate on chronic obstructive pulmonary disease exacerbations requiring hospitalization: a randomized placebo-controlled trial. Arch Bronconeumol. 2006;42(8):384-7.

160. Woodruff PG, Albert RK, Bailey WC, Casaburi R, Connett JE, Cooper JA Jr, et al. Randomized trial of zileuton for treatment of COPD exacerbations requiring hospitalization. COPD. 2011;8(1):21-9.

Ready to submit your research? Choose BMC and benefit from:

- fast, convenient online submission

- thorough peer review by experienced researchers in your field

- rapid publication on acceptance

- support for research data, including large and complex data types

- gold Open Access which fosters wider collaboration and increased citations

- maximum visibility for your research: over $100 \mathrm{M}$ website views per year

At BMC, research is always in progress.

Learn more biomedcentral.com/submissions 